\title{
ANALISIS PEMBINAAN PRESTASI KLUB BULUTANGKIS PB JUNIOR DI KABUPATEN BENGKULU SELATAN
}

\author{
Tito Parta Wibowo, M.Pd ${ }^{1}$, Juwita, M.Pd ${ }^{2}$ \\ ${ }^{1}$ Pendidikan Jasmani Universitas Dehasen Bengkulu \\ ${ }^{2}$ Pendidikan Jasmani Universitas Dehasen Bengkulu \\ email : titopartawibowo@gmail.com ${ }^{1}$,juwitarhazes@ gmail.com ${ }^{2}$
}

\begin{abstract}
ABSTRAK
Tujuan penelitian ini adalah untuk mengetahui gambaran, faktor Pembinaan Prestasi Bulutangkis PB Junior terhadap atlet, Pelatih, Program latihan, Managemen Organisasi dan Sarana Prasarana pada Cabang olahraga bulutangkis di Kabupaten Bengkulu Selatan. Penelitian ini merupakan penelitian deskriftif yang memiliki makna mendeskripsikan suatu penelitian yang sedang dilaksanakan. Populasi penelitian ini adalah atlet bulutangkis PB Junior Kabupaten Bengkulu Selatan yang berjumlah 20 orang, yaitu: 15 Laki-laki, dan 5 Perempuan. Teknik pengambilan sampel dilakukan dengan teknik total sampling. Teknik pengumpulan data yang digunakan dalam penelitian ini adalah dengan menyebarkan angket kepada responden yang menjadi sampel atau dengan metode penyebaran angket atau kuesioner kepada atlet. Analisis data dilakukan dengan mengolah data menggunakan rumus persentase. Kesimpulan penelitian bahwa Pembinaan Prestasi Klub Bulutangkis PB Junior Di Kabupaten Bengkulu Selatan dalam variabel atlet kategori sangat baik $(95,00 \%)$, variabel Pelatih kategori sangat baik $(90,00 \%)$, variabel program latihan kategori baik $(77,50 \%)$, variabel manajemen kategori cukup $(60,00 \%)$, serta varibel sarana dan prasarana kategori cukup $(50,00 \%)$.
\end{abstract}

Kata Kunci : Pembinaan Prestasi, Bulutangkis

\section{ABSTRACT}

The purpose of this study was to determine the description, the factors of Badminton Performance Development PB Junior against athletes, coaches, training programs, organizational management and infrastructure in badminton sports in South Bengkulu Regency. This research is a descriptive research which has the meaning of describing a research that is being carried out. The population of this study were 20 badminton athletes PB Junior Bengkulu Selatan Regency, namely: 15 male and 5 female. The sampling technique was carried out by using a total sampling technique. The data collection technique used in this research is by distributing questionnaires to respondents who are the sample or by distributing questionnaires to athletes. Data analysis was performed by processing data using a percentage formula. The conclusion of this research is that the PB Junior Badminton Club Achievement Development in South Bengkulu Regency in the category of athlete variable is very good (95.00\%), the variable of coach is very good category (90.00\%), the variable of the training program is in good category (77.50\%), the management variable is in the moderate category $(60.00 \%)$, and the facility and infrastructure variable is in the moderate category (50.00\%).

Keywords: Achievement Development, Badminton 


\section{PENDAHULUAN}

Permainan Bulutangkis merupakan cabang olahraga yang banyak digemari oleh masyarakat diseluruh dunia termasuk Indonesia. Hal ini dapat dilihat dengan banyaknya masyarakat yang ikut serta dalam setiap kegiatan olahraga bulutangkis yang diselenggarakan, baik dalam bentuk pertandingan tingkat desa hingga tingkat dunia, seperti Thomas dan Uber cup atau Olimpiade. Olahraga bulutangkis dapat dimainkan mulai dari anakanak hingga dewasa dan dapat dilakukan didalam maupun diluar ruangan. Di Indonesia bulutangkis dikenal juga dengan nama badminton. Olahraga Bulutangkis (Badminton) merupakan salah satu cabang olahraga yang paling popular di masyarakat Indonesia dewasa ini, karena lewat Bulutangkis lah Indonesia dikenal oleh seluruh dunia, apalagi masa jaya-jayanya para pahlawan bulutangkis Indonesia terbukti dengan hadirnya nama-nama besar pemain bulutangkis Indonesia seperti Rudi Hartono, Liem Swieking, Susi Susanti, Taufik Hidayat dan lain-lain, yang pernah mengharumkan bangsa Indonesia lewat ajang bulutangkis, bahkan pernah menjuarai kejuaraankejuaraan internasional terutama waktu merebut medali emas Olimpiade Bercelona, Indonesia berhasil meraih dua medali emas, melalui Alan Budi Kusuma pada tunggal putera dan Susi Susanti pada tunggal puteri. Disamping itu diperoleh juga medali perak dan Medali perunggu.

\begin{tabular}{lrrr}
\multicolumn{2}{c}{ Bulutangkis } & merupakan \\
olahraga prestasi & yang mampu \\
membawa bangsa & Indonesia ke
\end{tabular}

prestasi tingkat dunia. Dengan adanya prestasi yang membanggakan itu, maka olahraga bulutangkis tidak lepas dari pembinaan dalam latihan. Menurut Undang-Undang RI Nomor 3 Tahun 2005 Tentang Sistem Keolahragaan Nasional Bab VI Pasal 20 Ayat 1 berbunyi : "Olahraga prestasi dimaksudkan sebagai upaya untuk meningkatkan kemampuan dan potensi olahragawan dalam rangka meningkatkan harkat dan martabat bangsa”. Prestasi olahraga bulutangkis dalam pembinaanya tidak berbeda dengan cabang olahraga yang lain, dasar kualitas latihan yang merupakan penentu prestasi atlet juga dipengaruhi oleh banyak faktor. Adapun faktor-faktor tersebut, seperti yang diungkapkan oleh Harsono:

"Konsekuensi yang logis dari sistem latihan dengan kualitas yang tinggi biasanya adalah prestasi yang tinggi. Kecuali faktor pelatih, ada faktorfaktor yang lain yang mendukung dan ikut menentukan kualitas training yaitu hasil penemuan penelitian, fasilitas dan peralatan latihan, hasilhasil evaluasi dari pertandinganpertandingan, kemampuan atlet dan sebagainya" (Harsono, 1988: 119)"

Di Kabupaten Bengkulu Selatan sendiri sudah banyak berdiri Klub-Klub bulutangkis, salah satunya Klub yang akan menjadi tempat penelitian penulis yaitu Klub Junior. Klub ini termasuk klub yang sangat mendominasi prestasi bulutangkis di Kabupaten Bengkulu Selatan saat ini, terlihat dari beberapa event yang dipertandingkan beberapa club tersebut mampu mendulang prestasi. Tetapi saat ini pretasi bulutangkis di Bengkulu khususnya Kabupaten Bengkulu Selatan sangatlah menurun itupun terlihat dari 
beberapa event yang atlet Bengkulu ikuti diluar Provinsi Bengkulu. Seperti POPWIL, POPNAS, PRAPON dan lain-lain.

Adapun penyebab menurunnya prestasi bulutangkis di Kabupaten Bengkulu Selatan ini bisa saja disebabkan karena kurangnya menyelenggarakan event-event pertandingan sehingga kematangan dalam latihan pada atlet minim, disamping itu mungkin saja disebabkan karena atlet kurang mengikuti latihan secara rutin dan kotinyu, serta kurangnya sarana dan prasarana pendukung, dilain hal perhatian tentang penyeleksian atlet mungkin juga kurang menjadi prioritas apalagi dengan pemenuhan gizi atlet. Bertitik tolak dari uraian di atas sudah sepatutnya diperlukan pembinaan guna mengarahkan sekaligus melahirkan atlet bulutangkis yang handal dan berolahraga baik dalam tingkat nasional maupun internasional. Berdasarkan hal tersebut penulis memperkirakan bahwa kurang optimalnya prestasi bulutangkis di Kabupaten Bengkulu Selatan mungkin disebabkan kurangnya pembinaan dan latihan secara terstruktur dan terarah dan juga kurangnya perhatian pemerintah setempat dalam mendukung motivasi atlet dan pelatih untuk berprestasi di tingkat Nasional ataupun Internasional.

\section{METODE PENELITIAN}

Jenis penelitian ini adalah penelitian deskriptif, dimana penelitian ini bertujuan untuk mengungkapkan sesuatu apa adanya, dilakukan untuk melihat faktor Pembinaan Prestasi Bulutangkis PB
Junior terhadap atlet, Pelatih, Program latihan, Manajemen Organisasi dan Sarana Prasarana pada Cabang olahraga bulutangkis di Kabupaten Bengkulu Selatan. Dengan demikian penelitian ini berbentuk deskriptif, karena bertujuan untuk menguji hipotesis dari subjek yang diteliti. Menurut Maolani (2015:70), "Penelitian Deskriptif merupakan aktivitas yang bertujuan untuk menggambarkan situasi atau fenomena, yang dirancang untuk mendapat suatu informasi dalam keadaan sekarang".

Tempat penelitian dilakukan di GOR Padang Panjang Kabupaten Bengkulu Selatan. Waktu penelitian telah dilaksanakan pada bulan Januari 2020. Populasi didalam penelitian ini adalah klub olahraga bulutangkis yang ada di Kabupaten Bengkulu Selatan. Menurut Sugiyono (2018:130), "Populasi adalah keseluruhan element yang akan dijadikan wilayah generalisasi”. Berdasarkan observasi di lapangan serta informasi yang penulis peroleh dari pengurus klub Kabupaten Bengkulu Selatan, maka populasi dalam penelitian ini adalah atlet bulutangkis di klub Kabupaten Bengkulu Selatan yang melakukan pembinaan prestasi di klub bulutangkis dengan jumlah 20 orang atlet, terdiri dari 15 orang laki-laki dan 5 orang perempuan. Sedangkan sampel Menurut Sugiyono (2018:131) "Sampel adalah bagian dari jumlah yang dimiliki oleh populasi tersebut". Berdasarkan populasi tersebut di atas, maka yang dijadikan sampel dalam penelitian ini adalah atlet bulutangkis di klub pembinaan prestasi yang ada 
Kabupaten Bengkulu Selatan berjumlah 20 orang. Teknik dan alat pengumpulan data yang digunakan dalam penelitian ini adalah dengan menyebarkan angket atau kuesioner kepada responden yang menjadi sampel. teknik analisa yang dibutuhkan cukup dengan perhitungan persentase.

\section{HASIL DAN PEMBAHASAN}

Penelitian ini dilaksanakan di PB Junior di Kabupaten Bengkulu Selatan. Penelitian ini membahas tentang "Analisis Pembinaan Prestasi Klub Bulutangkis PB. Junior di Kabupaten Bengkulu Selatan“. Populasi penelitian ini sebanyak 20 orang. Penarikan sampel dilakukan dengan Total Sampling. Berdasarkan uraian di atas, maka yang di identifikasi terdiri dari 4 variabel yang masing-masing variabel adalah sebagai berikut : Berdasarkan hasil olahan deskriptif, diperoleh nilai skor dari atlet bulutangkis di Kabupaten Bengkulu Selatan adalah sebesar 95,00\%, skor tersebut menunjukkan potensi atlet bulutangkis Kabupaten Bengkulu Selatan tergolong Sangat Baik. Data yang diperoleh pada analisis terdahulu, dinyatakan bahwa beberapa faktor yang menjawab kurang meningkatnya prestasi bulutangkis di Kabupaten Bengkulu Selatan. Faktor-faktor dimaksud adalah : kurang lancarnya mekanisme organisasi dalam kepengurusan yang ada, kurangnya fasilitas sarana dan prsarana untuk latihan, dan program latihan yang belum akurat. Kesemua faktor di atas, merupakan penyebab kurang meningkatnya prestasi bulutangkis di Kabupaten Bengkulu Selatan. Hal ini berdasarkan data dan informasi yang berkaitan dengan pertanyaan penelitian terdahulu. Faktor ini perlu dibahas agar masalah kurang meningkatnya prestasi tersebut dapat diketahui lebih jelas. Berdasarkan hasil olahan diskriptif diperoleh nilai skor dari bagaimana pelatih telah melaksanakan program latihan di Kabupaten Bengkulu Selatan adalah sebesar $90,00 \%$, skor tersebut menunjukkan pelatih bulutangkis di Kabupaten Bengkulu Selatan tergolong Sangat Baik. Pelatih merupakan faktor yang sangat penting dalam pembinaan olahraga bulutangkis. Ditangan pelatih terletaknya peningkatan prestasi para atlet yang dilatihnya. Oleh karena itu seorang pelatih harus dapat membina dan mengembangkan bakat atlet ke tingkat prestasi maksimal dalam waktu yang relatif singkat.

Berdasarkan hasil olahan deskritif, diperoleh nilai skor dari program latihan bulutangkis di Kabupaten Bengkulu Selatan adalah sebesar 77,50\% skor tersebut menunjukkan program latihan bulutangkis di Kabupaten Bengkulu Selatan tergolong Baik. Program latihan dalam pembinaan olahraga bulutangkis merupakan faktor yang dominan dalam usaha meningkatkan prestasi para atlet. Suatu program akan mencakup proses persiapan, saat pelaksanaan dan saat akhir penyelesaian laporan yang berguna untuk menunjang pelaksanaan rencana latihan. Dengan kata lain program latihan merupakan pelaksanaan langsung suatu rencana latihan untuk mencapai tujuan yang diharapkan. Begitu pentingnya program latihan ini bagi seorang pelatih sehingga akan mempelancar proses latihan yang akan diberikan, 
sehingga akan membantu dalam melaksanakan pekerjaannya. Dalam program tersebut mencakup berbagi materi yang akan diterapkan kepada atlet sehingga pelatih akan mudah mengontrol atletnya karena adanya materi yang akan tersusun, maka atlet tersebut akan melakukan latihan, disiplin, sungguh-sungguh dan beraturan.

Berdasarkan hasil olahan deskriptif, diperoleh nilai skor dari mekanisme organisasi di Kabupaten Bengkulu Selatan adalah sebesar $60,00 \%$, skor tersebut menunjukkan mekanisme organisasi PBSI di Kabupaten Bengkulu Selatan tergolong Cukup. Organisasi merupakan satu hal yang pokok dalam pembinaan olahraga bulutangkis. Faktor organisasi merupakan wadah dari kegiatan olahraga yang memerlukan partisipasi dari seluruh anggota, masyarakat, dan pemerintah. Tanpa dukungan yang memadai, maka mekanisme organisasi itu tidak akan berjalan lancar. Kelancaran managemen organisasi olahraga bulutangkis akan menunjang terciptanya suatu prestasi yang optimal. Organisasi dipandang sebagai alat pencapaian tujuan yang telah ditetapkan sebelumnya, yang strukturnya bersifat relatif permanent tanpa menutup kemungkinan terjadinya reorganisasi apabila hal itu dirasa perlu, baik demi pencapaian laju usaha dan tujuan maupun dalam usaha efisiensi, efektif dan produktifitas kerja.

Sarana dan prasarana merupakan salah satu unsur yang menetukan dalam rangka pembinaan dan peningkatan kualitas atlet bulutangkis. Berdasarkan data dan informasi yang diperoleh maka diketahui sarana dan prasarana bulutangkis di Kabupaten Bengkulu Selatan tergolong cukup itu dilihat dari nilai skor yang dipilih oleh responden sebesar 50,00\%. Sarana dan prasarana merupakan aspek yang sangat penting dalam pembinaan prestasi bulutangkis, begitu juga hal pencapaian tujuan yang diharapkan dari sarana dan prasarana yang sangat menunjang. Penyediaan sarana dan prasarana olahraga bulutangkis dalam meningkatkan prestasi para atlet merupakan faktor yang ikut menentukan keberhasilan dalam pembinaan, tanpa penyediaan sarana dan prasarana yang memadai, maka prestasi yang diharapkan sukar tercapai.

\section{KESIMPULAN DAN SARAN}

Adapun kesimpulan dan dalam peneliti ini adalah sebagai berikut: Atlet yang berada di Kabupaten Bengkulu Selatan mempunyai potensi yang sangat baik untuk meningkatkan prestasi olahraga bulutangkis dan motivasi atlet untuk latihan itu karena kemauan mereka sendiri, bukan karena paksaan orang hasil persentase 95,00\%. Pelatih bulutangkis di Kabupaten Bengkulu Selatan melaksanakan latihan dengan baik dan dikategorikan tergolong sangat baik, terbukti bahwa pelatih bulutangkis di Kabupaten Bengkulu Selatan telah melaksanakan latihan secara baik dan terprogram dengan sangat baik, hasil presentase $90,00 \%$. Program latihan bulutangkis di Kabupaten Bengkulu Selatan telah dilaksanakan dengan baik dan dikategorikan baik, terbukti bahwa program latihan bulutangkis di 
Kabupaten Bengkulu Selatan telah merancang latihan secara tertulis dan terprogram baik jangka pendek mapun jangka panjang, dengan hasil presentase $77,50 \%$. Managemen organisasi olahraga bulutangkis yang berada di Kabupaten Bengkulu Selatan belum menjalankan tugasnya dengan baik dan dikategorikan Cukup, dengan persentase 60,00\%. Dan penyediaan sarana dan prasarana olahraga bulutangkis di Kabupaten Bengkulu Selatan dikategorikan cukup atau lengkap, dengan persentase $50,00 \%$. Sedangkan saran adalah Walaupun potensi atlet sangat baik, maka atlet harus menjaga dan terus mengasah kemampuannya dengan berlatih lebih giat agar bisa membawa Kabupaten Bengkulu Selatan dapat berprestasi di Porprov dan kejuaraan-kejuaraan lainnya.

\section{DAFTAR PUSTAKA}

Harsono. (1988). Coaching dan Aspek-Aspek Psikologis dalam Coaching. Jakarta:Tambak

Kusuma.

Maolani, Rukaesih dan Cahyono Ucu. (2015). Metodologi Penelitian Raja Grafindo Persada. Pendidikan. Jakarta: PT.

Sugiyono. (2018). Metode Penelitian Kuantitatif. Bandung: Alfabeta

Undang-undang Nomor 3 Tahun. (2005). Sistem Keolahragaan Nasional. Jakarta. 